Journal of Nepal Geological Society, 2019, vol. 59, pp. 59-64

DOI: https://doi.org/103126/jngs.v59i0.24988

\title{
Morphology and depositional setting of the sinkhole affected Armala area, Kaski District, western-central Nepal
}

\author{
*Basant Bhandari ${ }^{1}$, Jivan Bhusal ${ }^{2}$, Ramamohan Pokharel ${ }^{3}$, and Lalu Prasad Paudel ${ }^{2}$ \\ ${ }^{1}$ Department of Geology, Tri-Chandra Multiple Campus, Tribhuvan University, Ghantaghar, Kathmandu, Nepal \\ ${ }^{2}$ Central Department of Geology, Tribhuvan University, Kirtipur, Kathmandu, Nepal \\ ${ }^{3}$ University of Bristol, Bristol, $U . K$. \\ *Corresponding author: basantgeo@gmail.com
}

\begin{abstract}
Armala area of the Kaski District of Nepal is a flat valley of the Kali Khola, which is suffering from sinkhole hazard since 2013. A large volume of gravels was transported by the Seti River originated from the Annapurna Range, and the Pokhara Valley and its peripheral regions like the Armala Valley were filled up. The filled-up material in the Armala Valley is calcareous clayey silt with very few gravels. The deposit along the Armala Valley is undergoing subsurface erosion due to flow of subsurface water resulting the formation of subsurface caves and ultimate formation of sinkholes. Present study was concerned about the landform and morphological setting of the area, sediment characteristics and depositional environment of the sinkhole-affected Armala area. Five types of depositional layers have been identified in the study area; their depositional history and depositional environment also have been interpreted on the basis of the sediment properties as fluvio-lacustrine type. Landform and depositional setting along the study area also seem to influence the sinkhole formation mechanism.
\end{abstract}

Keywords: Armala area, Sinkhole hazard, Landforms, Depositional setting at sinkholes

Paper Received: 29 Mar 2019

Paper Accepted: 1 Jun 2019

\section{INTRODUCTION}

The study area, Armala area of the Kaski District, westerncentral Nepal is situated at $1 \mathrm{~km}$ north-east from the Mahendra cave, Pokhara, is a sub-basin of the Pokhara Valley. This area lies in between $83^{\circ} 59^{\prime} 00^{\prime \prime} \mathrm{E}$ to $83^{\circ} 59^{\prime} 30^{\prime \prime} \mathrm{E}$ and $28^{\circ} 16^{\prime} 30^{\prime \prime} \mathrm{N}$ to $28^{\circ} 17^{\prime} 00^{\prime \prime}$ N. Like the Pokhara Valley, the Armala area also has been filled up by the large volume of layered clastic sediments such as gravel, silt and clay of Quaternary age, brought probably by a series of catastrophic debris flow events on the Seti River due to huge avalanche occurred in the Annapurna Range as stated by Yamanaka et al. (1982). Due to the sediment containing a huge amount of calcareous clasts and matrix, the soil around the area is highly water dissolvable. Therefore, the area is highly prone to underground caving and piping by the subsurface water resulting the formation of large numbers of sinkholes around the Armala area. Due to the presence of a large volume of calcareous material in the sediments, karst structures (e. g., subsurface flow channels, solution cavities and sinkholes) are widely developed both at the surface and subsurface areas (Gautam et al., 2000).

Koirala and Rimal (1996) have characterized the geological hazards in the Pokhara Valley and divided into debris flow hazard, karst hazard and landslide hazard, respectively. They have considered the Ghachok Formation to be most susceptible for karstification because of the high content of calcareous material such as the calc-rudites, deposits are suffering from karstification of different intensity producing solutions channels, chimneys and pinnales forming underground caves and cavities.

In case of Armala area, dissolvable calcareous silt and clay sediments seem to be main factor for development of sinkholes. Knowledge about local morphological setting and understanding of depositional setting and history of the study area is important to understand sinkhole formation in the study area.

\section{GEOLOGICAL SETTING OF THE STUDY AREA}

The Pokhara Valley is one of famous intermontane basin of the Nepal Himalaya. Many researchers have worked on the geology, morphology and Quaternary sediments on this basin. Hagen (1969), Gurung (1970), Hormann (1974) and Sharma (1975) are the earliest researchers to investigate the area. Hagen (1969) and Sharma (1975) have suggested that the Pokhara Valley is a tectonic basin formed during the Cenozoic Era but they haven't given the detailed process of tectonic development of it. Later, Yamanaka et al. (1982) have suggested four stages of tectonic development of the Pokhara Valley. Paudel and Arita (2002) have mapped the Pokhara-Kushma area and they have indicated the basement geology of the Pokhara Valley as PreCambrian Kunchha Formation of the Lesser Himalaya containing 


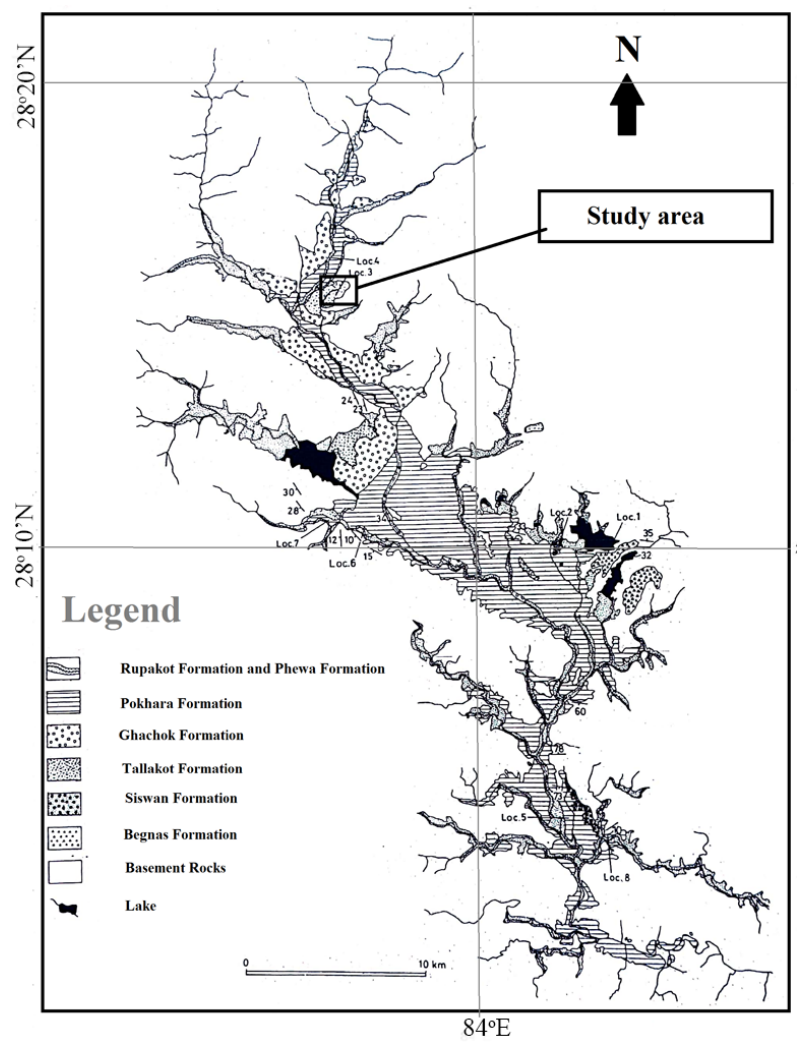

Fig. 1: Location of the study area and the Quaternary geological map of the Pokhara Valley (after Yamanaka et al., 1982)

fine- grained phyllite and metasandstone. They also have suggested the core of Pokhara-Gorkha anticlinorium passing through the Pokhara Valley.

Hagen (1969) and Sharma (1975) have stated that the Pokhara Valley was filled up by lacustrine deposit of a huge 'Paleo-Pokhara Lake' and several lakes in Pokhara Valley including Fewa, Begnas and Rupa as a remnant of that paleolake. But other researchers (Gurung, 1970; Hormann, 1974) have considered them as a result of damming of tributaries of the Seti River. Yamanaka et al. (1982) have also opinion in disagreement with the formation of huge paleo-lake as there is restricted distribution of lacustrine deposits along the periphery of the Pokhara Valley. Only fluvial gravels are found in the central part of the valley. The sediments from the Pokhara Valley were dated between 1,070 $\pm 100 \mathrm{yr}$ BP and yr BP (Yamanaka, 1982).

The Quaternary deposits of the Pokhara Valley are divided into nine stratigraphic units (Fig. 1) as: Begnas, Siswa, Tallakot, Ghachok, Phewa, Pokhara and Rupakot formations, gravel veneers on the fillstrath terraces carved in the Pokhara Terrace and recent flood plain deposit on the basis of unconformities and their lithofacies, respectively (Yamanaka et al., 1982). Among all these stratigraphic units, the study area belongs to the Ghachok Formation and Pokhara Formation. The Ghachok Formation has been represented by sub-angular to sub-rounded gravel of limestone, sandstone and shale derived from TibetanTethys Himalaya and Pokhara Formation is represented by lacustrine deposit of several meters thick containing laminated fine- grained sand, grey to light brown silt and organic clayey silt.

\section{MORPHOLOGY AND LANDFORM}

The study area is situated on the river valley of the Kali Khola, where the Duhuni Khola unites with the Kali Khola making a large alluvial fan. The Duhuni Khola is one of the tributaries of the Kali Khola, which is flowing through the sinkhole affected area. Sinkholes are concise on the distal portion of the fan. So, the study area has gentle topography. River channel, river valley and river fan are the major morphological features along the study area. There is also presence of a large flat plain made by the fluvio-lacustrine deposit of the Kali Khola (Fig. 2).

\section{DEPOSITIONAL CHARACTERISTICS OF THE SEDIMENTS}

Three detailed sedimentary $\operatorname{logs}(\mathrm{X}, \mathrm{Y}$ and $\mathrm{Z}$ ) have been prepared (Fig. 3), and each depositional layer in the area has been observed. The lithologs have been correlated on the basis of their position and their depositional characteristics. All lithology is found horizontal. In location ' $\mathrm{X}$ ', there is silt deposit at the bottom and it is overlain by the fining upward sequence of gravel to clayey silt (Fig. 3). There is depositional contrast between the bottom silt layer and the upper gravel to clayey silt layer indicating a sudden change in energy of depositional agent.

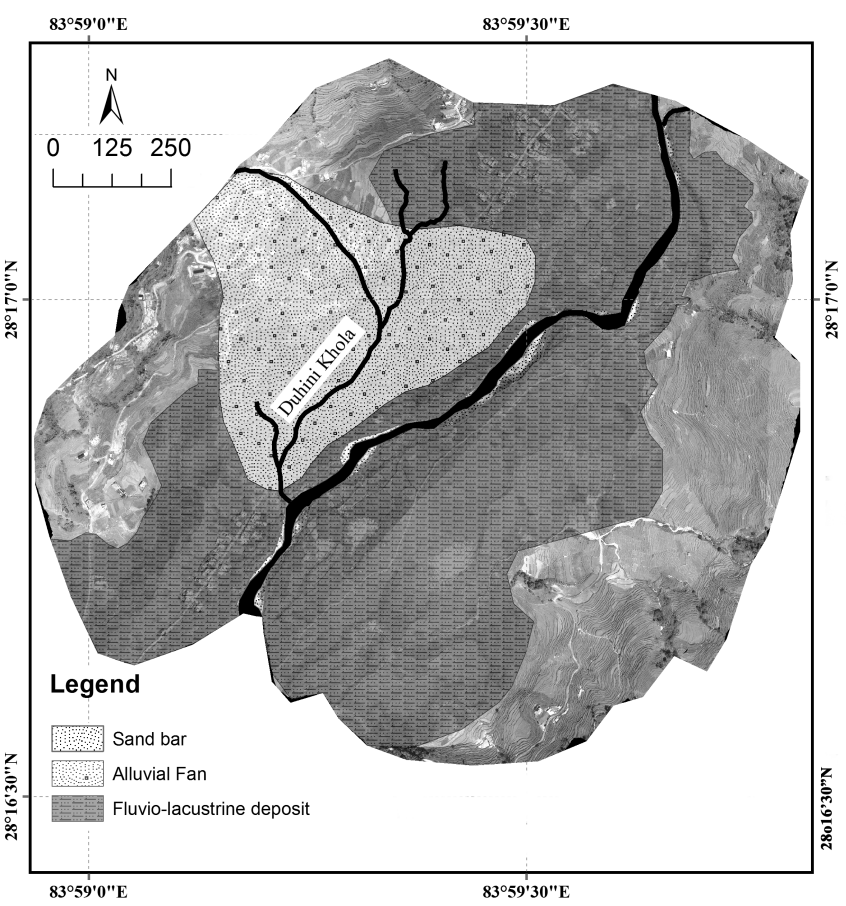

Fig. 2: Morphological setting of the study area 
This section lacks organic clayey silt deposit but such deposit of organic clayey silt is present on the location ' $\mathrm{Y}$ ' and location ' $Z$ ' (Fig. 3). This section also lacks the sand, which is present on the location ' $\mathrm{Z}$ '. Top two layers of organic clayey silt and sand on the location ' $\mathrm{X}$ ' might have been eroded away by the Kali Khola in the later phase but these are still preserved on the location ' $\mathrm{Y}$ ' and ' $\mathrm{Z}$ '.

In the location ' $\mathrm{Y}$ ', sharp contact between silt and organic clayey silt of dark grey color was observed. Lower light grey silt layer can be correlated with the fining upward sequence of the location ' $\mathrm{X}$ ' on the basis of the dark grey color and same texture, and their position (elevation). Upper dark grey organic clayey silt layer can be correlated with the same type of organic clayey silt deposit of the location ' $\mathrm{Z}$ '. This ' $\mathrm{Y}$ ' section lacks upper sand layer above the organic clayey silt deposit due to the erosion on the later phase by the Kali Khola.

In the location ' $\mathrm{Z}$ ', there is presence organic clayey silt layer of dark grey color on the bottom and sand layer and recent alluvial deposit at the top. The fining upward silt of light grey is not visible on the river section at this location because of the burial underneath the riverbed. The sand has been only on this section $(Z)$ among all three locations and was eroded away on other two sections.

In all three locations there is topmost layer of sub-angular to sub-rounded gravel of the Kali Khola, which cuts the sand layers on the location ' $\mathrm{Y}$ ' and both sand and organic clayey silt in the location ' $\mathrm{X}$ ' making an erosional unconformity.

On the basis of integrated litho-log of the study area (Fig. 4), five distinct sediments have been figured out. At the bottom of this log there is light grey stiff silt. It is followed up by cobble to pebble sized gravel on the basal part whereas grey stiff clay on the top. This unit exhibits fining upward sequence of the sediment particles, and has thickness of about $15 \mathrm{~m}$. This unit is followed by organic clayey silt which has thickness of about $10 \mathrm{~mm}$ and contains large amount of organic matters like leaf, barks and stem, etc. of various plants. This layer makes sharp contact with light grey silt on the base and sand at the top. Above clay, there is sand of about $1 \mathrm{~m}$. It sometimes has planner-cross stratification with a large proportion of medium to coarse sand. Finally, at top of the log there is very recent alluvial deposit of the Kali Khola (probably also of the Duhuni Khola). This has made erosional unconformity with lower sandy layer and has sub-angular to sub-rounded clasts come from near source.

\section{DEPOSITIONAL HISTORY AND SETTING OF THE STUDY AREA}

According to Yamanaka et al. (1982), the Pokhara Formation fills the valley sharply cutting the Ghachok Formation upstream from Pokhara town along the tributaries of the Seti River. They also have stated the Pokhara Formation as fluvial gravels accumulated by the Seti River and lacustrine deposit interfringing with gravels. They have described the characteristics of the Pokhara Formation from the Phusre Khola, Medhi Khola and other tributaries resembling with the sediments deposited along the study area. The sediments can be taken as the Pokhara Formation because these sediments cut the Ghachok Formation.

As stated by Yamanaka et al. (1982) the Pokhara Valley has been filled up by series of debris flow events originated from the Annapurna Range. The characteristics of sediments along the study area are also related to the debris flow events of the Seti River. The sediments carried out by Kali Khola along the study area sharply cut the Ghachok Formation (Fig. 5) and has fluvio-lacustrine characteristic as presented on the integrated sedimentary log of the study area. So, sediments along the study area must have been deposited after deposition of the Ghachok Formation. It was probably deposited during another debris

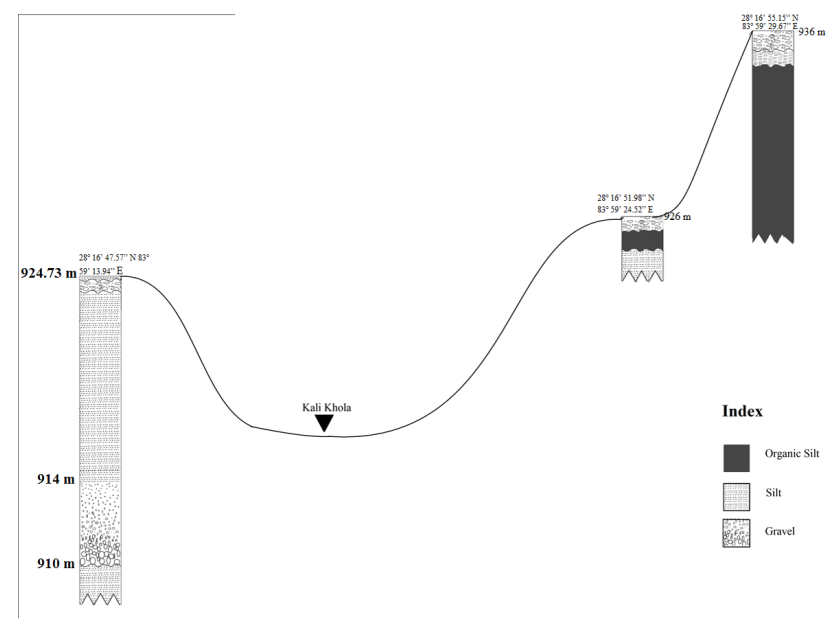

(E) Recent alluvial deposit of the Kali Khola

(D) Sand deposited by the Kali Khola while it was regaining higher energy

(C)

Organic clayey silt deposited on the paleolake formed by damming of the Kali Khola on the downstream section

Fining upward sequence of the cobble, pebble, granule, sand and silt after the settlement of the backwashed sedimend from the Ghachok Formation (B) derived by reverse current of the Kali Khola during the catastrophy on the Seti River

Fig. 3: Liho-logs from different sites and their correlation 
flow events happened after the event responsible for the deposition of the Ghachok Formation. That event might have dammed the Seti River downstream from the confluence between the Kali Khola and the Seti River. Due to which the current of the Seti River might have diverted towards the Kali Khola Valley generating large reverse-current. That reverse current might have cut the Ghachok Formation. The reworked sediment from the Ghachok Formation was settled down gradually on the lake formed by damming. The depositional history of each sedimentary sequence along the study area has been described on following sub-sections:

\section{Bottommost silt}

A silt layer on the bottom of the integrated lith-log (Fig. 4) reflects that it might have been deposited due to previous floods, which was similar to the event responsible for the deposition of upper layer.

\section{Fining upward of gravel to slit}

A fining upward sequence of gravel to silt superimposes the bottom silt layer (Fig. 4) that seems to be deposited by the reverse current came on the Kali Khola Valley flowing from the downstream section to upstream. The reverse current had carried the sediment cut from the Ghachok Formation along with it and finally deposited in the study area. The fining upward sequence indicates the gradual settlement of clast with respect to the time. The upper portion of the sequence has silt deposit as a result of damming of the Kali Khola on the downstream section.

\section{Organic clayey silt}

An organic clayey silt deposit just above the grey silt deposit (Figs. 4 and 6) exhibits dark-grey color because of abundant organic matters. During this phase of deposition, the lake became calm and stagnant. The organic deposit is situated



Fig. 5: Schematic cross-section of the Kali Khola on the further upstream section; this means there was formation of the marshy land on the peripheral part of the paleo-lake in the Kali Khola Valley. The organic deposit is of about $10 \mathrm{~m}$ thick. The plant grown there were buried, their leave, bark and stem have been found as fossil (Fig. 6).

\section{Sand}

There is sharp contact between organic deposit and silty layer of deposit (Figs. 4 and 7). Up to deposition of the organic clayey silt deposit, the existence of the Paleo-Kali Khola Lake was expected but at this phase of deposition the gradual extinction of lake might have taken place. The cross-bedded structures on the sand layer (Fig. 8) show the normal flow of the river from that time.

\section{Recent floodplain deposit}

The topmost deposition layer in the study area is floodplain deposit (Fig. 4). It is thick towards upstream section where it is up to $6 \mathrm{~m}$ thick and thinning towards downstream section. It cuts almost all depositional layers while going downstream from upstream making erosional unconformity. It is several meters thick from the recent riverbed. It indicates high rate of incision of the Kali Khola Valley, which also has been considered as the reason for sinkhole formation (Pokharel et al., 2015), since hydraulic gradient increases on lowering of the Kali Khola and subsurface water flows with higher velocity to result rapid erosion of the calcareous silt.

\section{ROLE OF MORPHOLOGY AND LANDFORM ON SINKHOLE FORMATION}

The sinkhole affected area is located along the geologically problematic landform because the area is covered by the alluvial fan of the Duhuni Khola over the river terrace made by the Kali Khola. The Duhuni Khola is one of the tributaries of the Kali Khola which is flowing from NW to SE



Fig. 6: Plant leaf fossil from organic silt deposit 
and before uniting with the Kali Khola it flows parallel with the Kali Khola and finally makes confluence. It has deposited alluvial sediments with mainly gravel and sand making a large alluvial fan over the fluvio-lacustrine terrace of the Kali Khola, containing large amount of calcareous silt and clay with some layers of fine sand.

Dhital and Giri (1993) have made engineering geological investigation at the collapsed Seti Bridge site, Pokhara. They have characterized and classified the sediment along the site and presented the example of karst-related destruction in the Pokhara Valley with reference of collapse of a highway bridge over the Seti River. But, in case of the Armala, karstification has very less role on the formation of the sinkholes.

Yagiura et al. (2017) have discussed about the progression of the fan of the Duhuni Khola and channel shifting mechanism of the Kali Khola. They have assumed four buried paleo-channels of the Kali Khola beneath the recent flat plain on the left bank of the Kali Khola. They also have suggested the distribution of the sinkhole along the old channel of the Kali Khola. This argument by Yagiura et al. (2017) is very logical and field verifiable. Additionally, not only channel of the Kali Khola seems to be shifted, but the channel of the Duhuni Khola also has been shifted making active and passive channels along the fan, which is typical characteristic feature of alluvial fan. The subsurface flow of water form proximal portion of fan is very favorable through previous passive channels to result subsurface erosion and ultimate formation of sinkholes (Fig. 9). Therefore, the Duhuni Khola can be taken as main source of subsurface water responsible for subsurface erosion of the silt.

Pokharel et al., (2015) believe active erosion process beneath the ground surface as a reason for sinkholes formation. Similarly, Rijal (2017) has described silt and fine sand sized particle as main reason behind formation of sinkhole because these particles are being eroded by subsurface piping mechanism. Both arguments have considered the active subsurface erosional

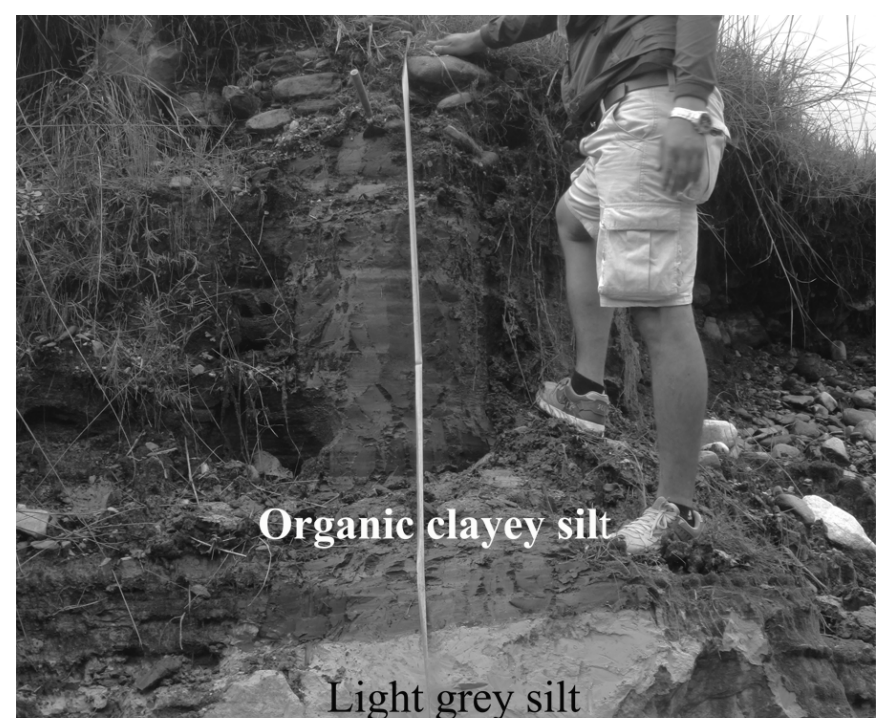

Fig. 7: Contact between organic clayey silt and light grey silt process as the reason for the sinkhole formation. Present study supports their augments with consideration of the many subsurface passive channels of the Duhuni Khola in the fan to be responsible for the subsurface erosional process resulting many subsurface caves and ultimate formation of sinkholes after collapse of these caves.

\section{CONCLUSIONS}

Armala area lies on the Pokhara Formation, which cuts the Ghachock Formation to form fluvio-lacustrine terraces along the river valley of the Kali Khola. Gravel containing clasts of limestone, quartz, gneiss interfringing with calcareous greenish grey to light grey colored silt, clay and fine sand are characteristic sediment types in study area.

The sinkholes are concentrated along the terrace on the right bank of the Kali Khola, especially on the distal fan made by the Duhuni Khola. There must be some roles of the fan for the formation of sinkholes. The sinkholes are ultimately formed due to the subsurface erosion of the water dissolvable calcareous silt by subsurface water.

Five types of depositional units (the bottommost silt, fining upward gravel to slit, organic clayey silt, sand and recent floodplain deposit) have been identified along the study area. Among them the bottommost silt had been deposited during the previous debris event on the Seti River, whereas, the fining upward sequence above it was resulted by the recent debris flow event. Organic clayey silt was deposited on the lake formed by damming of the Kali Khola on the downstream section due to the large amount of debris of the Seti River. Sand layer was deposited while the Kali Khola was getting higher energy due to gradual extinction of the debris dammed lake.

\section{ACKNOWLEDGEMENT}

Authors are thankful to the Central Department of Geology,

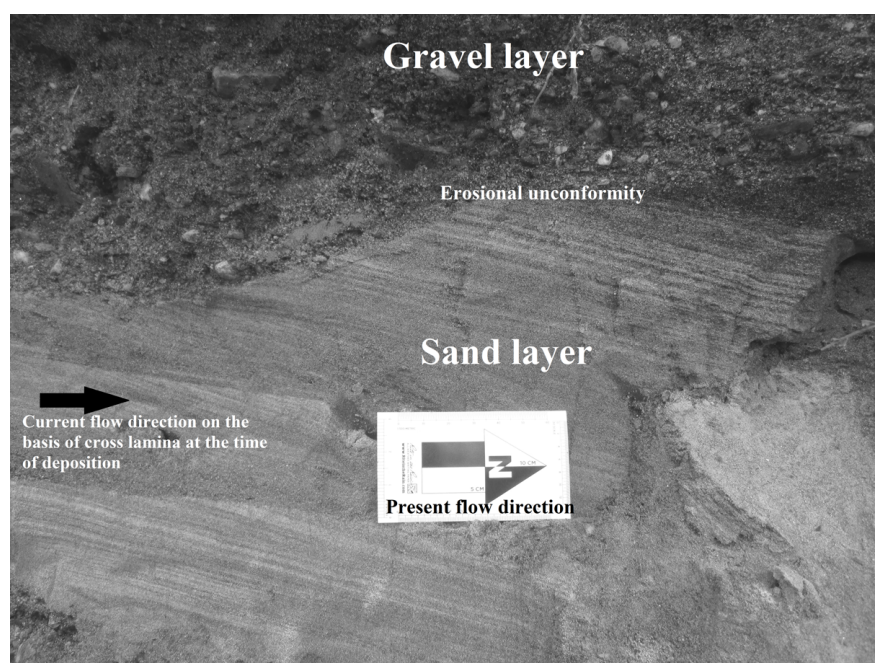

Fig. : Sand showing current flow direction on the basis of cross lamina 


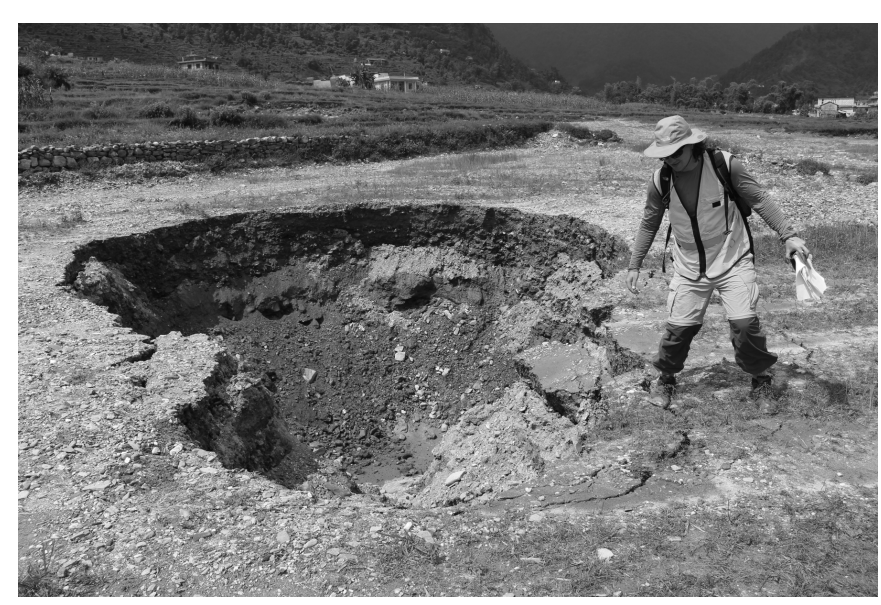

Fig. 9: A sinkhole from the Armala village

Tribhuvan University for providing research environment. Authors are also thankful to the local peoples of Armala, Kaski for their cooperation during the field work.

\section{REFERENCES}

Dhital, M.R. and Giri, S., 1993, Engineering geological investigation at the collapsed Seti Bridge site, Pokhara. Bulletin of Department of Geology, Tribhuvan University, v. 3, pp. 119-141.

Gautam, P., Pant, S.R., and Ando, H., 2000, Mapping of subsurface karst structure with gamma ray and electrical resistivity profiles: A case study from Pokhara Valley, Central Nepal. Journal of Applied Geophysics, v. 45, pp. 97-110.

Gurung, H., 1970, Geomorpology of Pokhara Valley, in Himalaya, Review, v. 1-2, pp. 37-49.

Hagen, T., 1969, Report on the geological survey of Nepal. Preliminary reconnaissance. Deankschiiften der Schweizerischen Naturforschenden Gesellschaft, Memories de la Societte Helvetique Des Science natures, Zurich, v. $86,185 \mathrm{p}$.
Hormann, K., 1974, Computer Based Climatological Map for High Mountain Area. A discussion paper, symposium on Mountain Environment Management, $33 \mathrm{p}$.

Koirala, A. and Rimal, L.N., 1996, Geological hazards in Pokhara Valley, western Nepal. Journal of Nepal Geological Society, v. 13, pp. 99-108.

Paudel, L.P. and Arita, K., 2000, Tectonic and polymetamorphic history of the Lesser Himalaya Central Nepal. Journal of Asian Earth Science., v. 26, pp. 561-584.

Pokhrel, R.M., Kiyota, T., Kuwano, R., Chiaro, G., Katagiri, T., and Arai, I., 2015, Preliminary Field Assessment of Sinkhole Damage in Pokhara, Nepal. International Journal of Geoengineering Case Histories, v. 3, pp. 113-125.

Rijal, M. L., 2017, Characterization of sinkholes affected area of Thulibeshi Phat, Armala, Kaski, Nepal characterization of sinkholes affected area. Journal of Institute of Science and Technology, v. 22, pp. 17-24.

Sharma, C. K., 1975, Natural Resources of Pokhara Valley. Navana Printing Works Private Limited, 47 Ganesh Chander Avenue Calcutta. 106 p.

Yagiura, Y., Takemasa, M., Yoshikawa, T., Kiyota, T., Katagiri, T., Ikeda, T., and Pokhrel, R. M., 2017, Follow-up survey of sinkhole damage in Pokhara, Nepal - Riverbed lowering and subsequent groundwater lowering causing numerous sinkholes in Pokhara, Nepal Since 2013. Proc. of the 7th Japan-Taiwan Workshop on Geotechnical Hazard from Large Earthquake and Heavy Rainfall, September 2016, PingTung, Taiwan.

Yamanaka, H., 1982, Radiocarbon ages of upper quaternary deposit in Central Nepal and their geomorphological significance. The science reports of Tohoku University, 7th series (geography), v. 32, pp. 46-60.

Yamanaka, H., Yoshida, M., and Arita, K., 1982, Terrace Landform and Quaternary Deposit Around Pokhara Valley, Central Nepal. Journal of Nepal Geological Society, v. 2, pp. 95-112. 